\title{
KEKERASAN DALAM HUBUNGAN PACARAN DI KALANGAN MAHASISWA : STUDI REFLEKSI PENGALAMAN PEREMPUAN
}

\author{
Intan Permata Sari \\ Sosiologi Universitas Indonesia \\ e-mail : Intanpermata312@gmail.com
}

\begin{abstract}
Abstrak
Artikel ini berfokus mengenai kekerasan dalam pacaran di kalangan mahasiswa. Kekerasan pada masa pacaran menarik diungkap, karena mengalami peningkatan setiap tahunnya. Korban kekerasan dalam pacaran cenderung perempuan. Akar permasalahannya, terdapat ketimpangan dalam relasi gender. Pertanyaan utama artikel ini adalah bagaimana proses terjadinya kekerasan dalam hubungan pacaran di kalangan mahasiswa? Serta bagaimana perempuan korban tetap mempertahankan hubungan tersebut? Padahal perempuan tersebut masih memiliki pilihan untuk putus. Berbeda halnya dengan perempuan yang terikat perkawinan. Temuan kualitatif, menunjukan alasan perempuan korban kekerasan dalam pacaran mempertahankan hubungannya tidak hanya dipengaruhi oleh faktor psikologis tetapi juga non-psikologis, termasuk faktor sosiologis, khususnya terkait cost dan benefit dalam relasi pacaran. Perempuan korban cenderung menjadi makhluk irasional dengan mempertahankan relasi pacarannya dengan pertimbangan keuntungan berupa terhindar dari social bullying melalui prestige dari status pacaran, dan terpenuhinya kebutuhan afeksi. Meskipun, harus mengorbankan waktu dan terjebak dalam hubungan kekerasan.

Kata Kunci : Kekerasan Dalam Pacaran (KDP), gender relation, Perempuan korban KDP

Abstract

This article focuses on the violence in dating college students. Dating violence attract disclosed, since has increased every year. Victims of dating violence tend to be female. Root of the problem, there is inequality in gender relations. The main question of this article is how the process of violence in dating relationships among college students? And how women victims still maintain this relationship? Though women still have the option to drop out. Unlike the case with the women who tied the marriage. Qualitative findings, indicating the reasons women victims of violence in dating maintain relationships not only influenced by psychological factors but also non-psychological, including the sociological factors, in particular related to the costs and benefits in dating relationship. Female victims tend to become irrational creatures to maintain relations with the consideration of the advantage of courtship avoid bullying through social prestige of dating status, and the fulfillment of affection. Though, it must sacrifice time and trapped in violent relationships.
\end{abstract}

Keywords: Dating Violence, gender relations, women victims of dating violence

\section{Pendahuluan}

Pacaran (dating) dilihat sebagai relasi antara laki-laki dan perempuan yang saling memiliki keterikatan secara emosional, karena adanya perasaan istimewa (Katz \& Arias, 1999). Perasaan tersebut dapat diartikan sebagai perasaan cinta, 
kasih sayang, dan rasa memiliki satu sama lain. Oleh karena itu, tidak jarang muncul pendapat bahwa dalam masa pacaran tidak akan memicu terjadinya tindak kekerasan, karena diliputi oleh nuansa romantisme dan kasih sayang (Ramadita, 2012). Namun faktanya, merujuk Catatan Tahunan (CATAHU) Komisi Nasional AntiKekerasan Terhadap Perempuan tahun 2016 mengindikasikan terjadinya peningkatan kasus kekerasan dalam pacaran dalam beberapa tahun terakhir, yang meningkat dari $21 \%$ di tahun 2015 menjadi $24 \%$ di tahun 2016. Angka kekerasan dalam masa pacaran memiliki pola yang sama setiap tahunnya dengan menduduki posisi kedua tertinggi pada kasus Kekerasan Dalam Rumah Tangga atau Relasi Personal (KDRT/RP) terhadap perempuan.

Berbagai studi juga memperkuat data CATAHU Komnas Perempuan, bahwa korban kekerasan dalam pacaran sebagian besar yaitu perempuan ( Lihat Tisya dan Rochana, 2009 ; Nataza, 2014 ; Powers \& Kerman, 2006: 2; Mulford and Giordano 2008 ). Kekerasan Dalam Pacaran juga menunjukan ketimpangan relasi antara laki-laki dan perempuan yang juga menjadi akar permasalahan (Tisya dan Rochana, 2009 ; dalam Kaura \& Lohman, 2007). Sayangnya, perempuan korban meskipun mengalami kekerasan dan bahkan hak-haknya terbelenggu (terampas) cenderung menerima dan memberi kesempatan (maaf) kembali terhadap pasangan yang melakukan tindak kekerasan (Foshee dalam Kaura \& lohamn, 2007). Sejalan dengan pendapat Horwitz \& Skiff (dalam Duley, 2012) yang menyatakan bahwa $40 \%$ sampai $70 \%$ perempuan korban kekerasan dalam pacaran mempertahankan kembali hubungannya dalam jangka waktu tertentu dan tidak jarang hingga melanjutkan ke pernikahan. Padahal sebagai manusia yang rasional, perempuan memiliki pilihan untuk memutus relasi pacarannya.

Beberapa kajian mengenai dating violence, menunjukan beberapa faktor yang melatari perempuan korban bertahan dalam relasinya. Pertama, faktor psikologis (Ramadita, 2012; Pramesti, 2014; Putri, 2012) bahwa perempuan cenderung mengalami kecemasan khususnya pada usia emerging adulthood, menurut Arnet (2004) usia emerging adulthood merupakan fase usia 18 - 25 tahun dengan periode perkembangan baru, dimana individu 
mulai mengeksplorasi identitas, salah satunya dalam hal hubungan percintaan. Memutuskan hubungan dengan pasangannya dianggap suatu keputusan yang merugikan, karena pada dasarnya perempuan pada usia tersebut memiliki tujuan untuk menikah. Sehingga ada kecemasan terhadap resiko sosial berupa perasaan malu jika tidak memiliki pasangan pada usia tertentu. Dengan demikian, perempuan memilih mempertahankan hubungannya dengan harapan pasangannya dapat berubah (Ramadita, 2012). Penelitian ini cenderung hanya terfokus pada dorongan yang muncul dari dalam diri individu. Berupa kecemasan, ketakutan serta rasa ketidaknyamanan jika memutuskan hubungan dengan pelaku. Kurang memperhatikan aspek diluar diri individu yang dapat mempengaruhi keputusan korban kekerasan dalam pacaran untuk mempertahankan hubungannya. Pada dasarnya tindakan yang dilakukan oleh individu merupakan bentuk dari stimulus sosial.

Kedua, faktor non-psikologis yang menjadi faktor di luar diri individu (Putri, 2012; Kisriyati, 2012). Dalam penelitian terkait kekerasan domestik yang dialami oleh perempuan, Abbott, dkk (2005) lebih menekankan pada perbedaan karakteristik dan latar belakang individu, diantaranya perbedaan status sosial-ekonomi sebagai pemicu munculnya tindak kekerasan. Didukung oleh pernyataan Kisriyati (2012) yang menyatakan bahwa terdapat ketergantungan baik secara materi dan non-materi pada pasangan, seperti terbiasa diantar jemput, dihadiahi suatu barang serta dibayarkan makanan yang membuat korban sulit lepas dari pelaku. Dalam relasi ini, perempuan korban cenderung menerima (pasrah) terhadap kekerasan yang dialaminya.

Dengan demikian, dari berbagai penelitian, mengindikasikan bahwa terdapat faktor baik yang datang dari dalam maupun luar diri individu, namun cenderung disajikan secara terpisah dalam melihat alasan perempuan korban mempertahankan relasi pacarannya. Akan tetapi, studi ini melihat bahwa terdapat pertimbangan mengenai keuntungan dan kerugian yang membuat kedua faktor tersebut tidak dapat dipisahkan. Oleh karenanya, studi ini menjelaskan kekerasan dalam pacaran dipicu dengan adanya kontrol terhadap sumber daya (materi dan non-materi) oleh salah satu pihak yang menimbulkan relasi 'Kekuasaan dan Ketergantungan' antara 
perempuan dan laki-laki. Dimana kontrol terhadap sumber daya dipengaruhi pola relasi yang dibentuk oleh motivasi dan karakteristik pasangan. Alasan perempuan korban kekerasan mempertahankan relasi pacarannya karena terdapat pertimbangan keuntungan berupa terhindar dari social bullying melalui prestige status pacaran dan terpenuhinya kebutuhan akan afeksi. Meskipun, harus mengorbankan waktu dan terjebak dalam hubungan pacaran yang penuh dengan kekerasan.

Pacaran merupakan hubungan yang dijalin oleh individu yang saling berinteraksi. Dalam interaksinya, setiap individu akan menggunakan pikirannya untuk mengukur sejauh mana hubungan tersebut akan mendatangkan manfaat. Hal ini akan dijelaskan melalui teori pertukaran, George Homans (dalam Ritzer, 2012) menyatakan inti dari teori pertukaran adalah rasionalitas individu dalam kontribusinya terhadap proses interaksi sosial. Konsep utama yang melandasi teori pertukaran yaitu utilitarianisme, yang melihat motivasi sebagai dorongan utama untuk melakukan suatu tindakan. Motivasi ini berkaitan dengan hal - hal yang sifatnya menguntungkan atau merugikan bagi individu. Terjadi proses kompromi dalam diri individu yang akan mempertimbangkan terkait cost dan benefit dari tindakan yang dilakukan. Cost dapat diasumsikan sebagai bagian yang harus dikorbankan oleh aktor. Sedangkan, Benefit adalah hal yang dikejar oleh aktor, karena merupakan sesuatu yang dipandang bermanfaat oleh aktor (dalam Klein dan White, 2007).

Terdapat beberapa asumsi dasar yang digunakan sebagai landasan dari teori pertukaran (dalam Klein dan White, 2007). Diantaranya, "the individual is real" yang melihat individu sebagai subjek yang utuh, yang memiliki motivasi tersendiri untuk dapat melakukan apa yang dikehendakinya. Jika kebanyakan teori besar memandang individu adalah sebagain kecil dari masyarakat, teori pertukaran 'mengakui' keberadaan individu. Bahkan, keberadaan individu sangat diperhitungkan, meskipun seseorang bertindak berdasarkan kehendak nilai dalam masyarakat, meskipun demikian, seseorang akan tetap menggunakan rasionalitasnya untuk bertindak. Setelahnya, terdapat asumsi "actors are motivated by selfinterest" yang menganggap bahwa apa yang dilakukan aktor berasal dari motivasi atas kepentingan aktor itu sendiri. Selanjutnya, asumsi "actors 
are rational", dimana individu dipandang sebagai subjek yang rasional dalam bertindak. Bersikap rasional, apabila seseorang memiliki kemampuan untuk menghitung rasio cost untuk mendapatkan sebuah benefit. Selain itu, ukuran rasional tiap individu sama, ketika ditempatkan pada situasi dan kesempatan yang sama. Maka orang akan menggunakan rasionalitas yang sama pula dengan tujuan untuk mengejar keuntungan yang sama.

Aktor yang terlibat dalam suatu relasi akan berusaha memaksimalkan keuntungannya. Namun, tidak jarang terhambat karena ada aktor lain yang juga memiliki tujuan yang sama, sehingga aktor dihadapkan pada pilihan-pilihan rasional dengan mempertimbangkan cost dan benefit, Coleman (dalam Ritzer, 2012) menyebutnya dengan Rational Chooise theory. Terdapat dua unsur dalam melihat teori ini yaitu, adanya aktor dan sumber daya. Sumber daya merupakan sesuatu yang dikontrol oleh aktor yang memiliki kepentingan atasnya. Aktor yang memiliki tujuan yang sama terlibat pada tindakan-tindakan yang sama yang akan berujung pada suatu sistem sosial (Coleman, 1990). Masing-masing aktor bertujuan akan memaksimalkan kepentingannya, yang ditandai karakter saling bergantung, sehingga aktor yang memiliki akses yang luas terhadap sumber daya akan cenderung menghasilkan subordinasi terhadap aktor lain, dengan tujuann tidak lain untuk memaksimalkan keuntungannya

Emerson (dalam Ritzer, 2012) mengemukakan bahwa dalam relasi yang tidak seimbang terdapat hubungan 'ketergantungankekuasaan', maksudnya adalah aktor yang memiliki kekuasaan berpotensi mempengaruhi aktor lain untuk menerima kehendak, sedangkan aktor yang mengalami ketergantungan memiliki potensi untuk mengalami kerugian karena harus mengikuti aktor yang berkuasa. Kekuasaan dan ketergantungan yang tidak setara menciptakan bentuk hubungan yang tidak seimbang. Aktor yang tidak terlalu memiliki ketergantungan, akan memiliki kekuasaan yang lebih besar. Jika ditarik pada tingkat yang lebih makro maka Coleman (dalam Ritzer, 2012) menyatakan bahwa pemaknaan norma dalam menjelaskan perilaku individu yang rasional dapat dilihat dengan seseorang yang menyerahkan sebagian kendali atas dirinya untuk memperoleh kendali parsial terhadap orang lain. Selain 
itu, internalisasi norma akan mendorong pemberian sanksi internal terhadap individu, apabila melakukan pelanggaran terhadap norma. Sehingga aktor cenderung berusaha mengendalikan dan menginternalisasi norma tersebut kepada orang lain.

Keterbatasan sumber daya yang dimiliki antara aktor satu dengan yang lain, dalam memperoleh tujuan yang sama mendorong aktor lain untuk lebih dominan. Hal ini juga terjadi dalam relasi gender. Dalam masyarakat patriariki, laki-laki lebih memiliki akses yang luas terhadap kepemilikan sumber daya dibandingkan perempuan, baik di ranah domestik maupun publik (Abbot, dkk, 2005). Ditandai dengan relasi hubungan yang timpang, karena pihak superordinat melakukan kontrol terhadap sumber daya kepada pihak ada pihak subordinat. Salah satu bentuk kontrol atau pengendaliannya melalui kekerasan dan penindasan. Jika masuk kedalam tahap penindasan berlandaskan gender maka terdapat pengaruh dari internalisasi sistem melalui norma.

Dalam gender oppression, ada usaha dari laki-laki yang memiliki kepentingan mendasar untuk mengontrol, menggunakan, dan menekan perempuan sebagai praktek dominasi. Ini dijadikan ajang untuk menunjukan dan mempertahankan kontrol. Bentuk kontrol tersebut beragam mulai dengan tidak mengakui kemandirian atau kebebasan pihak perempuan (subordinat), sehingga hanya dijadikan instrumen dari kehendak laki-laki (superordinat). Bentuk lain dari kontrol dan penaklukan dapat melalui kekerasan. Alasan seseorang menggunakan kekerasan sebagai bentuk kontrol diantaranya, terdapat single factor motivational yang meliputi adanya penyakit mental, perasaan cemburu, kebencian, overpermissivesnes dan ketiadaan kontrol sosial (keluarga) dalam pengalaman hidup seseorang (Abbot, dkk, 2005 : 272). Selain itu, juga terdapat kesalahan sosialisasi baik dari keluarga maupun lingkungan sosial. Apabila dalam keluarga atau lingkungan, individu disosialisasi melakukan pemecahan masalah dengan menggunakan kekerasan, maka dia akan cenderung menggunakan kekerasan. Saat sekarang kekerasan juga masih diyakini sebagai salah satu mekanisme yang paling kuat sebagai kontrol sosial.

Salah satunya dapat dilihat melalui kasus kekerasan dalam pacaran . Menurut Burandt, etl 
(dalam Muray, 2007) kekerasan dalam pacaran adalah suatu perilaku yang disengaja dengan menggunakan strategi kejahatan melalui paksaan untuk mendapatkan atau mempertahankan kontrol, kekuatan, terhadap pasangan. Perempuan menjadi sebagian besar korban tindak kekerasan dalam pacaran. Hal ini menunjukan bahwa perempuan dalam relasi pacaran memiliki power dan bargaining position yang lemah. Ditandai dengan perempuan mengalami kesulitan menegosiasikan kepentingannya kepada pasangan dan lebih memilih melakukan tindakan permisif dengan mentoleransi tindak kekerasan yang dialami.

Bentuk-bentuk dari kekerasan dalam pacaran menurut Shorey dkk, (2008) dan Rifka Anisa WCC Yogyakarta (2000) dapat dikelompokan sebagai berikut:

1. Kekerasan Fisik : kekerasan yang dilakukan terhadap pasangan berupa memukul, mencubit, menceki, menendang, atau melempar barang kepada pasangan yang dapat melukai dan menimbulkan bekas fisik terhadap pasangan.

2. Kekerasan Psikis : Kekerasan yang menyerang psikologis pasangan dapat berupa hinaan, mengkritisi secara berlebihan, merendahkan, menekan dengan ancaman yang dapat menimbulkan rasa bersalah terhadap pasangan dan membuat tekanan psikis lainnya.

3. Kekerasan Seksual : Kekerasan yang dilakukan terhadap pasangan dalam bentuk mengintimidasi, memaksa secara sengaja untuk melakukan kegiatan seksual, serta mengeluarkan komentarkomentar yang merujuk kepada konten pornografi.

4. Kekerasan Ekonomi : Bentuk kekerasan yang merugikan korban terkait financial baik bentuk uang maupun barang, tindakan yang dilakukan berupa pembatasan ruang gerak dalam kegiatan ekonomi atau melakukan pemerasan dan pemaksaan pemenuhan kebutuhan pasangan.

\section{Metode}

Penelitian ini menggunakan pendekatan kualitatif yang berfokus kepada proses menggali, melihat realitas sosial secara mendalam yang sarat akan makna dibalik suatu tindakan dan fenomena sosial (Neuman, 2003). Penulisan artikel ini bertujuan untuk menggali lebih dalam 
pengalaman perempuan yang menjadi korban kekerasan dalam berpacaran. Pengalaman perempuan itu digali dengan wawancara mendalam sebagai data primer. Data sekunder didapatkan melalui laporanlaporan komnas perempuan, jurnal dan bahan bacaan lainnya yang berhubungan dengan kekerasan dalam pacaran. Studi ini tergolong studi kasus karena melihat dan membandingkan beberapa kasus, sehingga diperoleh kedalaman data terkait isu yang diangkat.

$$
\text { Adapun kriteria subjek }
$$
penelitian ini adalah perempuan korban kekerasan dalam pacaran, berstatus mahasiswa, berada pada rentang usia emerging adulthood (18 - 25 tahun). Status mahasiswa dikaitkan dengan pilihan rasional perempuan dalam menentukan tindakan. Perempuan yang sudah berstatus mahasiswa seharusnya sudah berfikir lebih matang dan memiliki orientasi yang jelas dalam mengambil tindakan. Wawancara dilakukan terhadap dua orang yang telah dikenal oleh peneliti dan enam lainnya ditemui melalui purposive. Berikut karakteristik informan yang diwawancarai :
Tabel 1

Matriks Karakteristik Informan

\begin{tabular}{|c|c|c|c|c|c|c|c|c|}
\hline \multirow[t]{3}{*}{ No } & \multirow{3}{*}{$\begin{array}{l}\text { Inisial } \\
\text { Infomman }\end{array}$} & \multicolumn{7}{|c|}{ Karaktenistik } \\
\hline & & \multicolumn{2}{|c|}{ Usia } & \multicolumn{2}{|c|}{ Status Pakejaan } & \multirow{2}{*}{$\begin{array}{c}\text { Lama } \\
\text { Deppacarng }\end{array}$} & \multicolumn{2}{|c|}{ Pacarke-berapa } \\
\hline & & Informan & Pasmgan & \begin{tabular}{|l|l} 
Informan \\
\end{tabular} & Pasangan & & Infoman & \begin{tabular}{|l|l} 
Pasangan \\
\end{tabular} \\
\hline 1 & $\mathrm{DM}$ & $20 \mathrm{Th}$ & $21 . \mathrm{Th}$ & Mahasiswa & Mahasiswa & $\begin{array}{c}\text { Tahun } 8 \\
\text { Bulan }\end{array}$ & 4 & 5 \\
\hline 2 & $Y P$ & $21 \mathrm{Th}$ & $23 \mathrm{Th}$ & Mahadswa & Bekeng & 5 Tahun & 3 & . \\
\hline 3 & MY & 22 Th & $22 \mathrm{Th}$ & Mahasiswa & Mahasiva & $\begin{array}{c}1 \text { Tahun } 5 \\
\text { Bulan }\end{array}$ & 3 & Bayzak \\
\hline \begin{tabular}{|l|}
4 \\
\end{tabular} & BN & $19 \mathrm{Th}$ & $20 \mathrm{Th}$ & Mahagiwa & Mahasiwa & 3 Tahum & 1 & 1 \\
\hline 5 & EM & $21 \mathrm{Th}$ & $22 \mathrm{Th}$ & Mahasiswa & Mahasiswa & $\begin{array}{c}1 \text { Tahun } 11 \\
\text { Bulan }\end{array}$ & 6 & 3 \\
\hline 6 & $\mathrm{DL}$ & $22 \mathrm{Th}$ & $24 \mathrm{Th}$ & Mahasiswa & Bekeria & 1 Tahum & 2 & 5 \\
\hline 7 & WD & $23 \mathrm{Th}$ & $25 \mathrm{Th}$ & Mahasiswa & Bekenga & \begin{tabular}{|c}
1 Tahun 6 \\
Bulan \\
\end{tabular} & 3 & 4 \\
\hline 8 & NS & 23 th & $26 \mathrm{Th}$ & Mahagiswa & Bekeng & $\begin{array}{c}2 \text { Tahun } 4 \\
\text { Bulan }\end{array}$ & 2 & 5 \\
\hline
\end{tabular}

Sumber : Olahan Peneliti, 2016

Dalam studi ini diakui terdapat keterbatasan karena data hanya diperoleh dari perempuan yang mengalami kekerasan pacaran. Meskipun demikian, pengalaman perempuan berdasarkan kajian feminis dapat digolongkan sebagai realitas sosial yang dikonstruksikan kembali (Ritzer, 2012 : 773)

\section{Hasil dan Pembahasan}

Pola hubungan pacaran tidak bisa dilepaskan dari motivasi perempuan dan karakteristik pasangan. Berdasarkan delapan kasus, perempuan memiliki motivasi dalam menjalin hubungan pacaran diantara EM menyatakan :

"Seumuran kita (21 tahun), kayaknya memang udah wajar yaa butuh perhatian dari lawan jenis, kasih sayang, biar nggak jomblo-jomblo amat. Terus kayak nggak lengkap aja kalau nggak punya pacar." (wawancara bersama EM pada 5 November 2016) 
Ungkapan EM mewakili 6 informan lainnya yang menyatakan bahwa pacaran menjadi salah satu tuntutan dari lingkungan sosial, terutama pada usia tertentu. Kecederungan lain yang dapat dilihat berdasarkan data empiris dalam studi ini adalah kebutuhan afeksi menjadi motivasi yang kuat mendorong perempuan untuk berpacaran. Kebutuhan perempuan akan kasih sayang, perhatian dan cinta menjadi alasan kuat perempuan memutuskan untuk berpacaran. Salah satu motivasi menarik lainnya adalah berpacaran untuk menghindari social bullying, diantaranya malu jika menyandang status 'jomblo'. Ini diartikan sebagai kondisi seseorang yang masih lajang pada usia tertentu.

Pandangan mengenai 'jomblo' diperparah ketika lingkungan melabel status ini sebagai hal yang negatif, memalukan, diartikan tidak diminati lawan jenis, dan hal lain yang membuat efek malu jika menyandang status tersebut. Selain itu, perempuan (YP dan NS) pacaran juga dilihat sebagai salah satu cara untuk memilih calon suami.

Hal ini mengindikasikan perempuan menempatkan pacaran sebagai hubungan yang membawa dampak positif sebagai hiburan, memperoleh status dari lingkungan, kesempatan mengeksplorasi dan untuk mendapatkan kebutuhan afeksi. Tidak hanya itu, perempuan melihat relasi pacaran sebagai bagian dari proses pemilihan pasangan hidup (menikah). Terutama muncul pada perempuan yang memiliki pasangan dengan status sudah bekerja. Perempuan dikatakan sebagai individual yang real, dalam bertindak perempuan didorong oleh motivasi. Meskipun disatu sisi, keputusan perempuan dalam menjalani pacaran banyak dipengaruhi oleh faktor dari luar seperti perasaan malu dan takut dengan 'cemooh' masyarakat, namun berdasarkan apa yang disampakan Klein \& White (2007) bahwa individu sebagai subjek yang utuh, yang memiliki motivasi tersendiri untuk dapat melakukan apa yang dikehendakinya. Banyak motivasi yang mendorong perempuan untuk menjalin hubungan pacaran, namun hal ini tidak lepas dari keputusan yang berlandaskan motivasi dalam diri perempuan. Motivasi ini bersifat dinamis, motivasi awal perempuan dalam menjalin hubungan pacaran akan berbeda saat tengah menjalani hubungan pacaran.

Dalam menjalani hubungan pacaran perempuan memiliki kepentingan, tidak sedikit yang 
menginginkan hubungan pacaran yang dijalani berujung pada pernikahan. Tujuh dari Informan menyatakan bahwa mereka berharap pasangan dalam hubungan pacaran kelak akan menjadi suami. Salah satu informan menyatakan bahwa ada kecemasan dalam dirinya apabila harus melajang seumur hidup, hal ini dikarenakan salah satu saudaranya menikah pada usia yang cukup tua, sehingga dalam diri Informan terdapat kepentingan membawa hubungan pacaran kejenjang kepernikahan. Dalam studi ini hanya Informan EM yang tidak berniat untuk melanjutkan hubungan ke jenjang pernikahan, karena terbatas kepentingannya yang disebabkan oleh perbedaan agama antara EM dan pasangannya, sehingga untuk melanjutkan ke jenjang pernikahan akan ditentang kuat oleh orang tua. Motivasi perempuan untuk menjalin hubungan pacaran tidak dapat dilepaskan dari kepentingan dirinya. Baik kepentingan jangka panjang (pernikahan) maupun kepentingan jangka pendek ('teman jalan' dan 'teman curhat').

Karakteristik pasangan juga menjadi faktor pendorong perempuan dalam memutuskan untuk menjalin hubungan pacaran. Perempuan beranggapan pasangan dengan status sebagai seorang mahasiswa maupun yang sudah bekerja memiliki prospek yang lebih baik. DL menyatakan orang tuanya akan mengizinkan menjalin hubungan pacaran apabila pasangan tersebut minimal juga berstatus mahasiswa, sedangkan untuk Informan yang telah memiliki pasangan dengan status bekerja menyatakan membutuhkan yang 'mapan' lebih baik sebagai pendamping hidup. $\mathrm{Hal}$ ini menggambarkan status pasangan menentukan harapan perempuan terhadap hubungan pacaran. Ini memperlihatkan bahwa perempuan merupakan makhluk yang rasional dengan mempertimbangan keuntungan yang akan diperoleh dalam hubungan pacaran, dengan melihat prospek pasangan, Klein \& White (2007) menyebutnya sebagai "actors are rational". Perempuan akan mencoba memaksimalkan keuntungan tersebut berdasarkan karakteristik pasangannya. Salah satu tolak ukur dalam pencapaian keuntungan dapat dilihat seberapa jauh akses dan kontrol seseorang terhadap sumber daya, baik material maupun non-material. Kepemilikan sumber daya yang timpang dalam suatu hubungan akan berkecenderungan membentuk relasi 
yang tidak setara (Superordinat vs Subordinat). Hubungan dikatakan timpang tidak hanya melihat satu pihak memiliki sumber daya, sedangkan yang lainnya tidak. Namun, lebih kepada akses terhadap sumber daya tersebut. Perempuan dan pasangan memiliki sumber daya yang berbeda dan akses yang berbeda terhadap sumber-sumber daya tersebut.

Hubungan yang tidak seimbang akan ada bentuk pengendalian dan kontrol dari pihak Superordinat. Hal ini dilakukan tidak lain untuk menunjukan dan mempertahankan kontrol dalam memaksimalkan keuntungan. Salah satu bentuk kontrol yang dilakukan yaitu melalui kekerasan. Pacaran yang dianggap sebagai relasi yang diliputi nuansa romantisme dan saling mengasihi menjadi hubungan yang mengancam bagi perempuan. Perempuan korban mengalami kekerasan baik yang mereka sadari maupun tidak. Informan cenderung menutupi kekerasan yang dialami dengan melakukan penolakan (self denial) dengan sulit membedakan kasih sayang dan tindak kekerasan. Adapun bentuk kekerasan yang dialami oleh perempuan dalam hubungan pacaran sebagai berikut :
Pertama, Kekerasan psikis dimana kekerasan dalam bentuk ini memang sulit teridentifikasi namun memberikan dampak yang besar terhadap perempuan korban. Hasil temuan penelitian menunjukan hampir semua perempuan mengalami kekerasan dalam bentuk kekerasan psikis. Ditandai dengan sikap possessif dengan pengekangan ruang gerak tanpa alasan yang jelas, dibatasi untuk mengikuti kegiatan diluar kuliah, dibatasi bergaul bersama teman, bahkan dibatasi waktu berkumpul bersama keluarga, sehingga perempuan korban lebih banyak menghabiskan waktu bersama pasangan. Terlihat dari kutipan wawancara bersama Informan:

"Jadi harapan Aku, Aku main sama siapa Dia join aja gitu kan, nyambung aja, tapi malah realitanya Aku yang ditarik Dia gitu, Aku yang nggak main sama siapasiapa. terus teman-teman Aku. Jadi dibatesin gitu ruang geraknya. Misalnya Aku ditraktir teman Aku yang lagi ulang tahun yang lagi ramerame. Terus tau-tau Dia bilang kamu pulang sekarang" (wawancara bersama MY pada 11 November 2016)

Marah yang berlebihan jika perempuan korban dianggap salah atau tidak mengikuti keinginan dari pasangan (DL, MY, NS, dan YP), 
juga menjadi bentuk kekerasan psikis yang banyak dialami oleh perempuan korban. Awal munculnya kekerasan diawali dengan marah, sehingga tidak jarang pelaku membentak, berteriak, berkata kasar di depan umum dengan menyebut pasangan dengan 'tolol', 'bego','jablai', 'anjing, 'bangsat' 'binal' dan lain sebagainya yang membuat perempuan korban merasa dipermalukan. Ancamanancama juga dilancarkan oleh pelaku baik itu ancaman melukai korban maupun ancaman melukai diri sendiri, yang memberi efek takut dan bersalah terhadap korban. Namun, hal ini jarang dilaporkan karena memang sulit untuk mendapatkan bukti kekerasan.

Kedua, kekerasan fisik, menjadi kekerasan yang biasanya diikuti dengan perasaan takut yang mendalam bahkan menimbulkan trauma. Tiga (DM, MY, dan DL) Informan mengalami kekerasan fisik dalam bentuk menampar, mencekik, mencengkram hingga tercakar, memukul dengan benda dan mendorong korban hingga membentur dinding. Perempuan korban akan sulit membalas perlakuan pasangan dan biasanya hanya menangis. Informan menyatakan :
"Jadi kita yang debat-debat gitu, sampai Dia nyekek Aku ke tembok. Terus Aku ngeliatin gitu, Aku liatin, Aku liatin yang lurus gitu, lalu Dia ngerasa Aku tatap balik dengan tatapan datar gitu, Dia ngerasa nggak enak terus Dia lepas" (DM, Tanggal 18 November 2016)

Ketiga, kekerasan seksual, perempuan korban yang mengalami kekerasan seksual berupa pemaksaan berhubungan badan, berkomentar dengan konten yang mengarah kepada pornografi dan memaksa menonton video porno. Informan DM mengalami kekerasan seksual. DM menyatakan bentuk kekerasan yang dia alami mencangkup pemaksaan berhubungan badan, pemaksaan untuk melakukan tindakan yang tidak dinginkan oleh korban berupa melakukan 'anal seks', 'oral seks', dan menyakiti disaat penetrasi. Serta bentuk tubuh DM sering dibandingkan dengan pemeran perempuan yang ditonton pasangan di film porno. Salah satunya dengan mengirim Screenshoot foto perempuan tersebut kepada DM.

"Saya berhubungan seks sama dia, itu februari lalu, itu pun dengan pemaksaan. Maaf yaa kalau agak vulgar. Itu pas dia penetrasi itu kan agak sakit, karena itu pertama bagi Saya. Saat Saya meringis kesakitan, tetapi dia malah marah, 
menunjukan "Apaan sih lo, nggak bisa nahan banget sih". Dia sering memaksa berhubungan seks kadang ditempat- tempat yang misalnya diperpustakaan, di koleksi buku. Dia minta, Saya nolak, dia marah" (wawancara bersama informan DM. Tanggal 18 November 2016)

Terakhir bentuk kekerasan secara ekonomi, dimana perempuan korban merasa dirugikan secara financial. Adapun bentuk kekerasan ekonomi seperti dipaksa mengeluarkan biaya yang tidak diinginkan untuk pasangan. WD salah satu Informan yang sering mengalami kekerasan dalam bentuk ekonomi, namun sulit untuk melakukan perlawanan karena pasangan mengatas namakan cinta dan kasih sayang. Jika perempuan korban melakukan penolakan untuk memenuhi kebutuhan korban. Tidak jarang melakukan self blaming dengan menyatakan "kamu udah nggak sayang Aku", "Aku kira kamu beda dan ngerti keadaan Aku", "Kamu berhak dapat yang lebih baik dari Aku, karena Aku nggak pantas buat kamu". Sehingga ungkapan yang demikian, membuat perempuan korban yang terlanjur sayang menjadi tidak tega untuk melakukan penolakan dan melakukan tindakan permisif.
"Udah kesini-sini makin keliatan, kalau makan selalu gue yang bayar, kalau nonton gue yang bayar, bahkan untuk uang bensin motorpun gue yang bayarin. Emang gila banget tu orang. Yaa walaupun jalannya bareng gue juga" (WD, 10 Juni 2016)

Biasanya perempuan korban mengalami kekerasan berlapis, tidak hanya mengalami satu bentuk kekerasan namun juga diikuti bentuk kekerasan lainnya. Sebagian besar Informan mengalami kekerasan dua sampai tiga bentuk kekerasan sekaligus. Didukung juga dengan wawancara yang dilakukan dengan pihak komnas perempuan yang menyatakan bahwa jumlah kekerasan dalam pacaran akan mengalami tiga sampai empat kali lipat jika dicatat kedalam bentukbentuk kekerasan yang dialami oleh perempuan. Perempuan akan berada pada relasi yang timpang ketika lebih banyak melakukan pengorbanan terhadap pasangan, sedangkan apa yang diperoleh tidak sebanding.

Perempuan dan pasangannya saling berusaha memaksimalkan keuntungan dalam hubungan pacaran, sehingga pasangan yang memiliki sumber daya yang banyak akan memposisikan perempuan sebagai pihak yang mengalami ketergantungan dan secara alamiah siap untuk dikontrol oleh pasangan. 
Kesamaan dari hasil penelitian menunjukan bahwa perempuan mengalami 'ketergantungan' terhadap pasangannya. Beberapa Informan (YP dan NS) mengalami ketergantungan dengan harapan dapat menikah, karena pasangan sudah bekerja dan 'mapan'. Seringkali diberi barang, ditraktir makan, dan dikirimi uang membuat perempuan mengalami ketergantungan terhadap pasangan. Namun, ketergantungan ini semakin kuat apabila telah menjadi kebiasaan yang membuat perempuan cenderung memiliki power yang lemah dalam memutuskan tindakan. Ketergantungan material ini juga didukung oleh latar belakang ekonomi keluarga perempuan korban. Informan lainnya (MY, DM, $\mathrm{BN}, \mathrm{DL}$, dan WD) berkecenderungan mengalami ketergantungan nonmaterial berupa terbiasa mendapatkan perhatian dari pasangan, sehingga ada perasaan cemas jika pasangan berubah dan memutuskan hubungan. Salah satu Informan DL menyatakan kecemasannya apabila ditinggalkan oleh pasangan, mengalami perasaan takut kesulitan mendapatkan pasangan kembali, karena kurang bisa bergaul. Berdasarkan temuan data, semakin tinggi harapan perempuan terhadap pasangannya akan membuatnya berada pada posisi power yang lemah dan semakin rentan mengalami kekerasan dalam hubungan. Kekerasan menjadi pertanda bahwa perempuan memiliki bargaining position yang lemah, terbukti dengan sulitnya perempuan korban menegosiasikan kepentingannya Merujuk pada Emerson (dalam Ritzer, 2012) yang mengemukakan bahwa dalam relasi yang tidak seimbang terdapat hubungan 'ketergantungan-kekuasaan', perempuan yang memiliki ketergantungan yang besar terhadap pasangannya, maka akan cenderung dikuasai. Pasangan yang memiliki kekuasaan berpontensi mempengaruhi perempuan untuk menerima kehendak, sedangkan perempuan yang mengalami ketergantungan memiliki potensi untuk mengalami kerugian karena harus mengikuti kemauan pasangan. Perempuan yang memiliki banyak harapan terhadap pasangannya, seperti keinginan untuk melanjutkan kepernikahan, harapan dipenuhi kebutuhan afeksi dan materi membuat perempuan memiliki daya tawar yang rendah terhadap pasangannya. Selain harapan, lama berpacaran juga menjadi sumber 
ketergantungan perempuan. Semua Informan menjalin hubungan diatas satu tahun, perempuan memilih tetap bertahan karena sudah nyaman dengan hubungan yang dijalani. YP mampu mempertahankan hubungannya hingga 5 tahun, karena masih berharap pasangan bisa berubah, Selain memang sulit meninggalkan pasangan karena keluarga saling mengenal dan memiliki hubungan yang baik. DL memilih tetap mempertahankan hubungannya selama 1 tahun karena merasa malas untuk memulai lagi dari awal bersama orang lain yang belum tentu lebih baik dari pasangan yang sekarang. Kenyamanan yang didasari lamanya menjalin hubungan menjadi salah satu hal yang secara tidak langsung membuat perempuan memiliki ketergantungan semakin besar terhadap pasangannya.

Selain itu, keengganan perempuan untuk mengatakan 'tidak' (menolak) terhadap keinginan pasangan serta mudah menerima dengan memberikan maaf, membuat peluang perempuan kembali mengalami kekerasan semakin besar. Dengan demikian, jika dibiarkan terus menerus perempuan akan terjebak dalam siklus kekerasan. Sulit membedakan perasaan sayang dan cinta pasangan dengan kekerasan yang dialami. Adapun siklus kekerasan yang biasa dialami perempuan sebagai berikut.

Gambar 1. Siklus Kekerasan Terhadap Perempuan

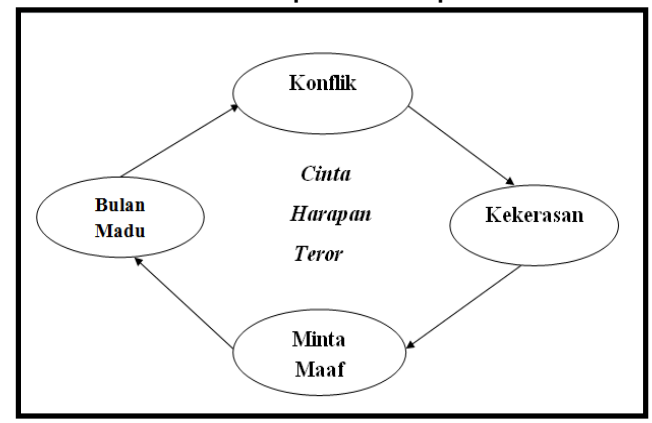

Sumber : Buku Pemetaan Kekerasan Komnas Perempuan, (2002)

Semua Informan penelitian mengalami keterjebakan dalam siklus kekerasan seperti gambar diatas, sehingga tidak jarang ada yang dapat bertahan hingga 3 sampai 5 tahun usia pacaran. Kekerasan diawali dengan pertentangan atau konflik, baik yang disebabkan oleh perempuan korban maupun pasangannya hingga terjadi tindak kekerasan. Kebanyakan Informan (DM, MY, WD, YP) menyatakan ketika awal terjadi kekerasan mereka melakukan perlawanan dengan meminta putus. Namun, pelaku akan melakukan permintaan maaf dengan berbagai cara supaya perempuan korban dapat memaafkan kembali. Informan MY menyadari adanya kekerasan dan melakukan perlawanan dengan meminta putus pada 6 bulan masa pacaran. Akan 
tetapi, luluh ketika pasangan meminta maaf.

"Pernah punya pikiran kayak gitu ada (melawan), dan dia pun mengemasi sampai sedemikian rupa kan. Dia mengkonstruksikannya itu yang sebagus itu, misalnya dia nampar itu yaa karena kamu tu gini-gini, $A k u$ tu ngelakuin kayak gini Karena yaa gini-gini. Jadi bikin Aku kayak ngerasanya apa Aku yang salah yaa. Jadi cenderung permisif gitu. Jadi bukan dia yang instrospeksi diri malah aku yang instrospeksi diri" (wawanacara bersama MY tanggal 11 November 2016)

MY menambahkan:

"yaa pastinya Aku marah yaa, apaan sih ni orang, tapi yaa itu dia bakalan ngasih-ngasih alasannya yang banyak, terus minta maaf, sampai yang nangis-nangis, yang sampai datang kerumah dan nggak mau pulang kalau Aku nggak mau ketemu, nggak Aku maafin. lyaa sampai yang kayak gitu, Aku tu diawal-awal dia udah nunjukin kalau dia posesif, Aku udah coba untuk mutusin, mungkin pada saat itu sebenarnya bisa, tapi karena Aku mikirnya dia yang udah minta maaf sampai yang nangis-nangis, apa dikasih kesempatan lagi, Terus setelah itu yaa udah dia juga kayak yang makin belajar gitu juga, ooo berarti bisa ni, kalau kayak gini" (Wawancara bersama MY pada 11 November 2016)

Perempuan yang memaafkan masuk kepada fase dimana hubungan lebih intim dibandingkan sebelumnya, hingga muncul konflik kembali dan terjadi secara berulang-ulang yang membuat perempuan sulit untuk lepas dari siklus kekerasan tersebut.

Banyak hal yang melatari alasan seseorang melakukan kekerasan, diantaranya terdapat 'single faktor motivational' yang berasal dari dalam diri pelaku, baik itu berupa penyakit mental, perasaan cemburu berlebihan, kebencian, ketamakan, over-permissivesnes dan ketiadaan kontrol sosial (Abbot, dkk, 2005 : 272). Hasil temuan penelitian, DL dalam wawancara menyatakan bahwa pasangannya sering mengalami cemburu buta dan memberikan tuduhan yang belum tentu kebenarannya. Setiap kali pasangan marah, maka tuduhan yang selalu diberikan adalah selingkuh. Sejalan dengan DM yang menyatakan bahwa pasangannya 'maniak seks' yang bisa colli (Istilah yang digunakan untuk melampiaskan hasrat seks dengan diri sendiri (onani) dua kali sehari. Kondisi pasangan DM yang demikian, membuat hal ini menjadi pemicu konflik antara keduanya. Berikut pernyataan DM :

Dia punya hardisk, itu isinya bokep semua. Dia punya kelainan Dia bakalan turn on kalau ngeliat cewe jilboobs. Itu yang bikin Aku kesel, Dia juga suka ngebandingin ukuran 
payudara Aku sama apa yang Dia liat di film bokepnya. Aku juga sering bilang kamu kurangin dong, terus Dia bakalan bilang emang kamu bakalan selalu ada deket Aku kalau Aku lagi kepengen (wawancara bersama DM pada 18 November 2016)

Selain itu tidak jarang kesalahan sosialisasi dalam keluarga maupun lingkungan mendorong seseorang melakukan kekerasan. MY dan DM memiliki pasangan yang berasal dari keluarga yang sering menggunakan kekerasan. MY menyatakan berdasarkan cerita pasangan, Ayahnya sering kali menyelesaikan masalah dengan lbu menggunakan tamparan atau kekerasan lainnya. Berdasarkan ungkapan pasangan tersebut meskipun pasangan tidak mengakui dia akan melakukan hal yang sama, akan tetapi berdasarkan perlakuan yang diterima oleh MY, pasangan cenderung melakukan hal yang sama dalam menyelesaikan masalah. Selain keluarga, lingkungan juga memiliki pengaruh yang besar dalam menyebabkan seseorang melakukan kekerasan. Salah satunya didorong melalui tuntutan laki-laki untuk maskulin dan tidak boleh menunjukan sisi lemah, sehingga hal ini termanifestasikan melalui kekerasan terhadap pasangan sebagai bentuk kontrol.

Perempuan

korban

mempertahankan hubungan pacarannya karena adanya pertimbangan bahwa keuntungan yang diterima masih lebih besar dibandingkan pengorbanan yang harus dilakukan. Berdasarkan hasil wawancara bersama Informan terdapat kesamaan pengorbanan yang dilakukan selama menjalin hubungan pacaran diantaranya, perempuan mengorbankan banyak waktu untuk dihabiskan bersama pasangan dibandingkan dengan teman-teman bahkan keluarga, terutama bagi perempuan korban dengan bentuk kekerasan possesif. Hampir semua perempuan korban kekerasan terasingkan dari lingkungannya karena harus mengikuti kemauan dan dikontrol oleh pelaku. Pengorbanan berikutnya yang dijalani oleh perempuan korban dengan penempatan dirinya sebagai perempuan yang mengalami tindak kekerasan. Hakikatnya tidak satupun perempuan korban menginginkan bertahan dalam hubungan tersebut, namun terdapat beberapa pertimbangan yang membuatnya memilih untuk bertahan. Tidak sedikit perempuan korban yang mengalami keterjebakan dalam siklus kekerasan 
menjadi alasan yang kuat untuk tetap mempertahankan

hubungan

pacarannya.

Meskipun demikian, baik secara sadar maupun tidak perempuan korban merasakan keuntungan dari hubungan pacaran, diantaranya mendapat prestige dari status pacaran dan secara tidak langsung terhindar dari social bullying. Bagi beberapa Informan ini menguntungkan dalam beberapa hal seperti, seperti ada perasaan bangga ketika memiliki pasangan, DL menyatakan ada perasaan bangga ketika dijemput oleh pasangan baik ketempat kuliah maupun kekampus. Memiliki pacar juga dijadikan tolak ukur dan pengakuan atas diri sendiri bahwa memiliki pacar mengindikasikan perempuan diminati oleh lawan jenis. Selain itu, terpenuhinya kebutuhan afeksi baik kasih sayang, cinta, maupun perhatian. Dari delapan kasus, perempuan korban cenderung tidak mendapati dirinya diselingkuhi oleh pasangan, sehingga pasangan memberikan perhatian penuh kepada perempuan, entah sebagai bentuk kepedulian atau sebagai bentuk kontrol atas perempuan.

Perempuan akan mempertimbangkan cost dan benefit dalam hubungan pacaran, sejalan dengan Homans (dalam Ritzer, 2012) yang mengatakan bahwa seseorang dalam setiap kesempatan akan berusaha memaksimalkan keuntungannya. Dalam hal ini perempuan dengan mempertahankan hubungannya menjadi salah satu bentuk memaksimalkan keuntungan, meskipun pada dasarnya perempuan masih memiliki pilihan untuk memutuskan hubungan pacaran. Secara rasional, perempuan korban kekerasan masih melihat hubungan pacaran yang dijalaninya memiliki keuntungan yang lebih besar, sehingga memilih bertahan dibandingkan dengan harus meninggalkan pasangan.

Namun, tidak jarang juga ada beberapa hal yang membuat perempuan korban mempertahankan hubungan, meskipun dalam perhitungan untung rugi, pengorbanan lebih banyak dikeluarkan dibandingkan dengan keuntungan yang diperoleh. Adapun hal tersebut sebagai berikut : Pertama, mitos keperawanan yang masih sangat kental dalam masyarakat membuat perempuan korban memilih mempertahankan hubungan pacarannya, karena terdapat perasaan insecure tidak bisa menemukan kembali pasangan yang mau menerima kondisi perempuan 
korban, terutama pada masyarakat yang menganggap keperawanan sebagai suatu hal yang sakral. Terpaksa mengikuti kemauan pelaku yang tidak jarang disertakan dengan ancaman. Informan DM menyatakan :

"Terus dia bilang Aku binal, karena udah nggak perawan. Padahal yang nggak merawanin yaa dia juga. Dia marah, terus tetap bilang Aku binal, liat aja lo ntar bakalan jadi digilir sama cowo-cowo, ngerokok, nongkrong ampe malam. Nggak ada yang bakalan mau lagi sama lo,binal" (wawancara bersama DM 18 November 2016)

Berdasarkan kutipan wawancara diatas dapat disimpulkan bahwa keperawanan dapat menjadi ancaman bagi pelaku terhadap perempuan korban. Pandangan masyarakat yang melihat perempuan yang tidak perawan sebagai perempuan yang berprilaku amoral, binal dan kotor. Membuat perempuan korban rentan kembali mendapat kekerasan jika berhasil lepas dari satu hubungan kekerasan, karena perspektif laki-laki secara umum akan dipengaruhi oleh nilai kultural yang dianut masyarakatnya, sehingga perempuan korban memilih mempertahankan hubungannya dan terjebak dengan anggapan masyarakat terkait dengan keperawanan.
Kedua, 'legal system marginalize'. Kekerasan dalam pacaran masuk kedalam kekerasan domestik / relasi personal. Jika diperhatikan kekerasan yang terjadi diranah domestik berbeda dengan kekerasan yang terjadi di komunitas maupun pada tingkat negara. Perbedaan yang mencolok adalah kekerasan dalam relasi personal antara korban dan pelaku saling mengenal, sehingga terdapat unsur trust dalam hubungan tersebut yang membuat peluang perempuan menjadi korban kekerasan semakin besar. Akan berbeda halnya ketika perempuan diajak keluar oleh pacar dibandingkan oleh orang yang tidak dikenal. Hal ini juga mendorong perempuan mengalami kebimbangan untuk melapor atau menceritakan kepada orang lain mengenai kekerasan yang dialami karena takut dianggap 'bodoh'. Mengingat kekerasan dalam pacaran belum memiliki payung hukum yang melindungi korban. Kekerasan yang terjadi dalam hubungan pacaran dalam proses hukum, akan dianggap sebagai kasus pidana kekerasan biasa. Bungkamnya perempuan korban karena seringkali orang lain menyalahkan karena atribut 'keperempuanannya'. 
Cost dan benefit dalam dikontrol, dikendalikan dan hubungan pacaran menjadi pertimbangan perempuan korban mempertahankan hubungan pacarannya. Akan tetapi, terdapat pertimbangan suatu kondisi yang memaksa perempuan untuk tetap memilih mempertahankan hubungan, meskipun Cost yang dikeluarkan lebih besar dibandingkan benefit yang diperoleh.

\section{Simpulan}

Hasil pembahasan terkait kekerasan dalam pacaran yang dialami korban perempuan tidak lepas dari relasi gender yang timpang, dikarenakan akses dan kontrol terhadap laki-laki lebih besar dibandingkan dengan perempuan. Kontrol dan pengendalian terhadap perempuan memiliki keterkaitan yang kuat dengan motivasi perempuan dan karakteristik pasangan. Harapan perempuan, lamanya hubungan pacaran serta keengganan perempuan untuk menolak mengikuti kemauan pasangan membentuk pola relasi 'kekuasaan dan ketergantungan'. Kekerasan dan ketergantungan perempuan berbanding lurus, semakin besar ketergantungan perempuan terhadap pasangannya, maka semakin besar pula peluang perempuan tersebut

mengalami kekerasan. Perempuan yang mengalami kekerasan dalam hubungan pacaran sebagian besar memilih untuk mempertahankan hubungannya, meskipun mempunyai pilihan untuk putus. Secara rasionalitas perempuan mempertimbangkan keuntungan berdasarkan sumber daya yang dipertukarkan dalam hubungan pacaran.

Namun, dalam hasil temuan penelitian menunjukan kelemahan penggunaan teori pertukaran Homans dan pilihan rasional Coleman. Teori ini, tidak mampu menjelaskan lebih lanjut mengenai tindakan perempuan mempertahankan hubungan pacaran meskipun cost yang dikeluarkan lebih besar dibandingkan benefit yang diterima. Terkadang perempuan memilih suatu tindakan tidak hanya melihat dirinya sebagai subjek yang mementingkan diri sendiri dalam memaksimalkan keuntungan, namun terdapat aspek struktur budaya yang tidak bisa diabaikan dalam mencapai kepentingan. Tidak sedikit perempuan mempertahankan hubungannya bukan karena alasan afeksi yang diterimanya, akan tetapi karena mengalami keterjebakan dalam hubungan yang membuat 
perempuan sulit lepas dan meninggalkan pasangan, sehingga bertahan menjadi pilihan yang memungkinkan dalam jangka waktu tertentu.

Bagi peneliti selanjutnya, hasil penelitian ini masih banyak mengalami kelemahan dan kekurangan. Terutama, dalam melihat aktor lain yang mempengaruhi perempuan korban kekerasan bertahan di luar pasangannya seperti ada peer group, orang tua dan media massa sebagai agen social bullying yang lebih banyak ditemukan saat ini. Selain itu dapat mempertimbangkan untuk melihat kekerasan dalam masa pacaran dari perspektif pelaku dan dihubungkan dengan kondisi budaya masyarakat setempat.

\section{Ucapan Terima Kasih}

Terima kasih kepada pihak yang telah membantu dalam penelitian dan penyusunan artikel ini. Antara lain Dr.Ida Ruwaida, M.Si selaku dosen pembimbing, Diatyka Widya Permata, MA dan Drs. Andi Rahman Alamsyah, M.Si dosen mata kuliah seminar, teman-teman perempuan korban kekerasan, dan pihak komnas perempuan. Terima kasih pula untuk redaksi Jurnal Dimensia yang sudah menerbitkan tulisan ini.

\section{Daftar Pustaka}

Abbott, Pamela, Claire Wallace, and Melissa Tyler. 2005. Beasley, Chris. 2005. "Introduction: Feminism and Sociological Imagination". In Pamela Abbot, Claire Wallace, and Melissa Tyler. An Introduction to Sociology, a Feminist Perspectives. Oxon, New York: Routledge, Taylor and Francis.

Arnett, Jeffrey. 2004. "Emerging Adulthood: The Winding Road From the Late Teens Through the Twenties". New York: Oxford University Press, Inc.

Babbie, Earl. 2010. "The Practice of Social Research 12th ed". Belmont CA: Wadsworth Cengage Learning

Duley, L.A. 2012. "A Qualitative Phenomenological Study of the Lived Experiences of Women Remaining in Abusive Relationships". Doctoral Dissertation.

Katz, J. \& Arias, I. 1999. "Psychological abuse and depressive symptoms in dating women: Do different types of abuse have differential effects?. " Journal of Family Violence.14 (1): 281-295

Kaura, S. \& Lohman, B. 2007. "Dating Violence Victimization, Relationship Satisfaction, Mental Health Problems, and Acceptability of Violence: A Comparison of Men and Women". Journal of Family Violence. 22 (1): 367-381

Kaura,S., Lohman, B., Scnurr, M. 2010. "Violence and Victims. Variation in Late Adolescents Reports of Dating Violence Perpetration: A Dyadic Analysis". Journal of Family Violence. 25 (1): 84 -25

Kisriyati. 2012. Makna Hubungan Seksual Dalam Pacaran Bagi Remaja Di Kecamatan Baureno Kabupaten Bojonegoro. 
Fakultas IImu Sosial. Universitas Negeri Surabaya

Komnas Perempuan. 2002. "Peta Kekerasan: Pengalaman Perempuan Indonesia". Jakarta: Ameepro.

Mulford, C. \& Giordano, P. 2008. Teen dating violence: $A$ closer look at adolescent romantic relationships. NIJ Journal, 261, 34-40

Nataza, Nabila. 2014. Studi Kasus Mengenai Strategi Coping Stress Pada Perempuan Emerging Adulthood Korban Dating Violence yang mepertahankan hubungan dengan pasangannya. Fakultas Psikologi. Universitas Padjadjaran

Noonan, R.K. \& Charles, D. (2009). Developing teen dating violence prevention strategies: Formative research with middle school youth. Violence Against Women, 15, 1087-1105.

Oudekerk, Demher, and Mulford. 2014. "Teen Dating Violence : How Peers Can Affect Risk \& Protective Factors ". U.S. Department of Justice Office of Justice Programs 810 Seventh St. N.W. Washington DC 20531.

Powers, Jane and Kerman,Erica. 2006. "Teen Dating Violence". Family Life Development Center . Cornell University

Pramesti, Anindya. 2014. "Studi Kasus Mengenai Cinta Pada Perempuan Emerging Adult Korban Kekerasan Dalam Masa Pacaran Yang Mempertahankan Hubungan". Skripsi Universitas Padjadjaran. Tidak dipublikasikan

Putri, Zandy. 2012. "Hubungan antara kekerasan dalam masa pacaran dan self esteem pada perempuan dewasa muda". Fakultas Psikologi. Universitas Indonesia
Ramadita, Marsha. 2012. "Hubungan Antara Kecemasan Dengan Acceptance Of Dating Violence Pada Diri Perempuan Dewasa Muda Korban Kekerasan Dalam Pacaran Di Jakarta “. Fakultas Piskologi. Universitas Bina Nusantara

Reputriwati, Any,. Murdijana,. Susilawati. 2000. "Janji Gombal". Rifka Annisa WCC Yogyakarta. Yogyakarta.

Ronfeldt, H., Kimerling, R, . Arias, I. 1998. "Satisfaction with Relationship Power and the Perpetration of Dating Violence". Journal of Marriage and Family. 60 (1): 70-78

Shorey, Ryan C., Cornelius, Tara L., \& Bell, Kathryn M. 2008. "A critical review of theoretical frameworks for dating violence: Comparing the dating and marital fields". Aggression and Violent Behavior. 13 (1): 185194

Tisyah dan Rochana. 2009. Analisa Kekerasan Pada Masa Pacaran (Dating Violence). Jurnal Sociologi. 1(1) :1-9

Klein, David M and James M. White. 2007. Family Theories : An Introduction. Sage Publication

Murray, Jill. 2007. But I love Him. HarperCollins e-book.

Neuman, W. L. 2003. Social Research Methods: Qualitative and Quantitative Approaches. 5th Edition. Boston: Allyn and Bacon

Lembar Fakta Catatan Tahunan (CATAHU) Komnas Perempuan Tahun 2015. Kekerasan Terhadap Perempuan :Negara Segera Putus Impunitas Pelaku. Jakarta, 6 Maret 2015. 